\title{
A review on Tinospora cordifolia: as an Immunomodulating agent
}

\author{
Available online at www.hjhs.co.in \\ REVIEW ARTICLE \\ Pritika Devi* \\ Assistant Professor, Dept. of Rasa Shastra \& Bhaishjya Kalpana, Babe Ke Ayurvedic Medical \\ College \& Hospital, Daudhar, Moga, Punjab, India. \\ DOI 10.22270/hihs.v6i1.88
}

\begin{abstract}
Guduchi is a plant also known as Tinospora cordifolia, having heart shaped leave, an herb of the family Menispermaceae native of hot areas of the Indian subcontinent. In our classical Ayurvedic texts, it is indicated to be beneficial in treating various types of diseases like skin disorders, different types of fever, jaundice \& gout. Guduchi also claimed to have various properties as an anti-oxidant, antihyperglycemic, antihyperlipidemic, hepatoprotective, cardiovascular protective, neuroprotective, osteoprotective, radioprotective, anti-anxiety, adaptogenic agent, analgesic, anti-inflammatory, antipyretic, athrombolytic agent, anti-diarrheal, anti-ulcer, antimicrobial and anti-cancer agent. Present paper is an attempt to assemble the information based on several experimental and clinical reports on immunomodulating role of Tinospora cordifolia.
\end{abstract}

Keywords: Tinospora cordifolia, Guduchi, plant extract, immunomodulator

\section{Introduction}

Immunomodulator can be defined as, any drug or its chemical constituents which can stimulate any component or function of the immune system in a specific or nonspecific way. This concept of immunomodulation is mentioned in Ayurveda as Rasayana. The use of specific herbs for improving the overall resistance of body against common viral, bacterial infections has been a managing principle of Ayurveda. These active agents used in various immunotherapies are collectively known as immunomodulators. They are used in various collection of recombinant, synthetic and natural preparations, often cytokines. Some of these substances such as granulocyte colony stimulating factor (G-CSF), interferon, imiquinol and cellular membrane fractions from bacteria are already licensed for use in patients. Others including IL-2, IL-7 and IL12, various chemokines, synthetic cytosine phosphate guanosine, oligodeoxynucleotides and glucane are investigated extensively in clinical and preclinical studies. Immunomodulatory treatments offer an eyecatching approach as these agents often have fewer side effects than existing drugs which are used commonly, including less potential for creating resistance in microbial diseases. (1) The holistic approach of Ayurveda to manage wide range of diseases includes dietary and lifestyle interventions as well as regimens of herbal/mineral based medicines. (2) Tinospora cordifolia (Family: Menispermaceae) a renowned medicinal vine of Ayurveda is reported to possess multidimensional biological properties. (3-5) Tinospora cordifolia (Family: Menispermaceae) is one of the most widely used plant from the Ayurvedic system of medicine. Tinospora cordifolia is commonly known as Amrita, Guduchi (Sanskrit), Giloe (Hindi) and its huge application in the treatment of various diseases. According to recent studies, the discovery of numerous active components from the plant and their biological function in the management of disease control has led to active interest across the world.

There are varieties of active components derived from this plant like alkaloids, steroids, diterpenoid lactones, aliphatics, and glycosides which have been isolated from the different parts of the plant, root, stem, and whole plant. Recently, Tinospora cordifolia is of great interest to all the drug researchers, pharma sector across the world because of its 
reported various medicinal properties. (6) From various reported studies and scientific data, it showed its use as anti-oxidant, antihyperglycemic, antihyperlipidemic, hepatoprotective, cardiovascular protective, neuroprotective, osteoprotective, radioprotective, anti-anxiety, adaptogenic agent, analgesic, anti-inflammatory, antipyretic, a thrombolytic agent, anti-diarrheal, anti-ulcer, antimicrobial and anti-cancer agent. It is also reported a good source of micronutrients viz. copper, calcium, phosphorus, iron, zinc and manganese. Mant studies are done by keeping on its health benefits as an immunity booster. In market, several patents have been filed which are under process and many are granted to inventions encompassing Tinospora cordifolia as a major component of dosage or formulation for enhancing metabolic, endocrinal and several other illnesses, helping in the improvement of human life expectancy. (7) Based on in vitro, pharmacological and clinical evidences it has been found that Tinospora cordifolia has immense immunomodulator potential. (8) The present is an attempt to review the immunomodulating property of Tinospora cordifolia.

\section{Methodology}

Tinospora cordifolia is used in therapeutics as a single herb (in various dosage forms) as well as is an essential ingredient of several polyherbal Ayurvedic formulations. (9) Several Ayurvedic dosage forms of Tinospora cordifolia are being used in traditional Ayurvedic practice as a rejuvenative, health promotive, as well as curative medicine. (10-14) Tinospora cordifolia is one of the components of several traditional formulations with potent rejuvenating, immunomodulatory, cytoprotective, and antioxidant properties. (15-17) Several published reports suggest potential bioactivities of Tinospora cordifolia in immune-enhancement and immune-protection (Table 1).

\section{Result \& Discussion}

Kapil at el studied the immunostimulating effect of leaves extract of Tinospora cordifolia. The study conducted on extract of the leaves of Tinospora cordifolia showed the insulin-like action and significantly reduced the blood glucose level. It is also studied that root has emetic properties which is used for visceral obstruction. TC-1 (clerodane furano diterpene glycoside), TC-2 (cordioside). TC-4 (syringin), TC-5 (cordifolioside A), TC, i5 (cordifolioside B) and TC-7 (cordiol) these chemical constituents are isolated from Tinospora cordifolia which are found to have anticomplement and immuno-stimulating activities. (25) Immunopotentiating activity was studied according to the technique followed by Ram et al. (1990). (26) Groups of five balb/c mice weighing 20-22 g were immunized subcutaneously with sheep red blood cells containing compound (200 and $500 \mu \mathrm{g} / \mathrm{ml}$ ) emulsified with Freund's incomplete adjuvant (FICA). The immunization done with Freund's complete adjuvant and SRBC alone, served as control. For the analysis of antibody response, serum was collected after 2 weeks and circulating $I g G$ antibodies to SRBC were assessed by enzyme linked immunosorbent assay (ELISA). (27) The compounds TC (Tinospora cordifolia )-1, TC-2, TC-4, TC-5, TC-6 and TC-7 exhibited enhancement of IgG antibodies. Increase in antibodies by TC1, TC-2 and TC-5 was $110-111$ and $115 \%$ at 100 and $500 \mu \mathrm{g}$ respectively. TC-4 showed $121 \%$ and TC-6 $118 \%$ at $500 \mu \mathrm{g}$. TC-4 and TC-6 these two were more active in enhancing immunoglobulins. TC-7 had the highest immunostimulating activity. (18)

The experimental study was performed by Gupta et al to study the immunomodulatory effect of Tinospora cordifolia. Twenty Swiss male albino mice were taken and divided into four groups of five mice each. The first group kept as control was administered (i.p.) with $0.1 \mathrm{ml}$ sterile isotonic saline. The second group of mice treated with $\mathrm{CCl}_{4}$ at a dose of $0.5 \mathrm{ml} / \mathrm{kg}$ b.w. (i.p.) administered in the last 7 days of the experiment. 
Table 1. Immunomodulatory profile of Tinospora cordifolia.

\begin{tabular}{|c|c|c|c|c|c|c|}
\hline Part & Extract & $\begin{array}{l}\text { Drug-induced } \\
\text { (animal mode) }\end{array}$ & Dose (mg/kg) & Duration & Effect & Proposed mechanism \\
\hline Root & Aqueous & Balb/c mice & $200 \& 500 \mu \mathrm{g} / \mathrm{ml}$ & 2 weeks & Immunomodulating & $\begin{array}{l}\text { The compounds TC-1, } \\
\text { TC-2, TC-4, TC-5, TC- } 6 \\
\text { exhibited enhancement of } \\
\text { IgG antibodies. (5) }\end{array}$ \\
\hline \multirow{5}{*}{ Stem } & \multirow{5}{*}{ Aqueous } & Male albino-20 & - & - & \multirow{5}{*}{$\begin{array}{l}\text { Ameliorating } \\
\text { immunosuppressive } \\
\text { effects }\end{array}$} & \multirow{5}{*}{$\begin{array}{l}\text { Increases the } \\
\text { phagocytosis capacity of } \\
\text { peritoneal macrophages } \\
\text { isolated from ccl4 } \\
\text { intoxicated mice. (19) }\end{array}$} \\
\hline & & $1^{\text {st }}$ group-5 albino & $\begin{array}{l}0.1 \mathrm{ml} \text { sterile isotonic } \\
\text { saline }\end{array}$ & 15 days & & \\
\hline & & $2^{\text {nd }}$ group-5 albino & $0.5 \mathrm{ml} / \mathrm{kg} \mathrm{CCl} 4$ (i.p.) & Last 7 days & & \\
\hline & & $3^{\text {rd }}$ group-5 albino & $\begin{array}{l}40 \mathrm{mg} / \mathrm{kg} \\
\text { extract orally }\end{array}$ & 15 days & & \\
\hline & & $4^{\text {rth }}$ group- 5 albino & $\begin{array}{l}40 \mathrm{mg} / \mathrm{kg} \quad \text { T.cordifolia } \\
\text { extract orally, CCl4 (i.p.) }\end{array}$ & $\begin{array}{l}\text { T.cordifolia extract- } 15 \\
\text { daysCCl4 (i.p.)- last } 7 \text { days }\end{array}$ & & \\
\hline $\begin{array}{l}\text { Whole } \\
\text { plant }\end{array}$ & Aqueous & Mice & $100 \mu 1-$ injection & $72 \mathrm{~h}$ & $\begin{array}{l}\text { Immunomodulatory } \\
\text { effect }\end{array}$ & $\begin{array}{l}\text { Primarily acts on the } \\
\text { macrophages and stim- } \\
\text { ulates the production of } \\
\text { effector molecules. }(20)\end{array}$ \\
\hline \multirow[t]{2}{*}{ Leaf } & Ethanol & Fin Fish & $0.8,8,80 \mathrm{mg} / \mathrm{kg}$ & 3 weeks & \multirow[t]{2}{*}{ Immunoprophylactic } & $\begin{array}{l}\text { Ethanol extract } \\
\text { significantly enhanced } \\
\text { neutrophil activity. (21) }\end{array}$ \\
\hline & Petroleum & Fin Fish & $0.8,8,80 \mathrm{mg} / \mathrm{kg}$ & 3 weeks & & $\begin{array}{l}\text { Petroleum ether extract } \\
\text { enhanced the secondary } \\
\text { antibody response. (21) }\end{array}$ \\
\hline $\begin{array}{l}\text { Whole } \\
\text { Plant }\end{array}$ & Aqueous & In vitro & $80 \mu \mathrm{g} / \mathrm{ml}$ & 48 hours & $\begin{array}{l}\text { Immunomodulatory } \\
\text { effect }\end{array}$ & $\begin{array}{l}\text { Macrophage } \\
\text { viability. }(22)\end{array}$ \\
\hline Stem & Alcoholic & Mice & $\begin{array}{l}12.5 \mathrm{mg} / \mathrm{kg} \text { in } 500 \quad \mu \mathrm{l} \\
\text { saline - injection }\end{array}$ & 72 hours & $\begin{array}{l}\text { Immunomodulatory } \\
\text { effect }\end{array}$ & Phagocytic activity. (23) \\
\hline Stem & $\begin{array}{l}\text { Alcoholic, } \\
\text { aqueous }\end{array}$ & In vitro & $100 \mu \mathrm{g} / \mathrm{ml}$ & Viability test -1 hour & $\begin{array}{l}\text { Immunomodulatory } \\
\text { effect }\end{array}$ & $\begin{array}{l}\text { Phagocytic activity on } \\
\text { Polymorphonuclear cells } \\
\text { (PMN Scale). (24) }\end{array}$ \\
\hline
\end{tabular}


The third group of mice were orally administered with extract of Tinospora cordifolia at dose of $40 \mathrm{mg} / \mathrm{kg}$ by feeding needle for 15 days. The fourth group of mice were administered with Tinospora cordifolia extract for 15 days, orally and $\mathrm{CCl}_{4}$ for last 7 days, intraperitoneal. (19) Phagocytosis assay demonstrated the effect of both $\mathrm{CCl}_{4}$ and Tinospora cordifolia on the number of differentiated macrophages, the macrophage cells of extensive rough surface or perfect spherical surface was measured and counted as morphologically altered macrophage. From this experiment, it was observed that $\mathrm{CCl}_{4}$ treated mice increased the number of altered macrophages. (28)

However the after the administration of Tinospora cordifolia in $\mathrm{CCl}_{4}$ intoxicated mice, the number of altered macrophages became almost normal level. Administration of Tinospora cordifolia in control group of mice also showed some significant reduction of altered macrophages. The study further evaluated the effect of Tinospora cordifolia on phagocytosis activity of peritoneal macrophages; isolated from $\mathrm{CCl}_{4}$ intoxicated male mice on phagocytosis index. $\mathrm{CCl}_{4}$ administration in control mice reduced the phagocytosis index. But after the administration of Tinospora cordifolia, the phagocytosis index of $\mathrm{CCl}_{4}$ intoxicated peritoneal macrophages are observed increased. Tinospora cordifolia treatment not only increases the phagocytosis index of $\mathrm{CCl}_{4}$ intoxicate peritoneal macrophages but also increased the phagocytosis index of control peritoneal macrophages. (19)

The study conducted by Upadhyaya et al, reported that the aqueous extract of Tinospora cordifolia has active immunomodulatory properties. The study of plant extracts have been mainly focused on the activation of splenocytes and lymphocytes by the Tinospora cordifolia extract through the augmentation of production of cytokines. The production of cytokine is the method to examine the augmentation activity of the immune system that have important role to control the homeostasis of whole organism.
The aqueous extract of Tinospora cordifolia treated mice increased the nitric oxide [NO] production by the macrophages, when the animals stimulated with LPS (Lipopolysaccharides). It is also observed that $1 \mathrm{mg} / \mathrm{kg}$ of extract showed the notable enhancement in production of nitric oxide. Various textual references considered the role of Nitric oxide in the regulation of the immune response to tumours. In this study, it showed the dose dependent production of nitric acid. The increased in the nitric oxide production was supposed to have been due to the cascade of the signalling pathway. In conclusion, this data further supports the important role of macrophage in production of nitric oxide by direct lysis of B16F10 melanoma cells in vitro. (20)

The experimental study conducted on fishes by Sudhakaran et al has shown remarkable the immunostimulatory effect of Tinospora cordifolia extract. This study was conducted on leaves and the extraction of leaves in ethanol, petroleum ether media. Both ethanol and petroleum ether extracts managed at doses of $0.8,8$ or $80 \mathrm{mg} / \mathrm{kg}$ body weight, up to one to three weeks. The ethanol extract Tinospora cordifolia at the dose of 8 $\mathrm{mg} / \mathrm{kg}$ showed the secondary antibody response, where the Tinospora cordifolia petroleum ether extracts showed the same effect at the doses of 0.8 or $8 \mathrm{mg} / \mathrm{kg}$. After observing whole study, it is found that the ethanol extract significantly enhanced neutrophil activity. Although this study was done on fishes, when injected with these extracts at the dose of $8 \mathrm{mg} / \mathrm{kg}$, they protected the fishes against experimental infection virulent A hydrophila. Overall result indicated the immunoprophylactic potential of Tinospora cordifolia leaf extracts to prevent diseases in finfish aquaculture. (21)

A study by More $P$ et al revealed that macrophages cells are first line of defence mechanism and plays important role in innate and specific immunity. The aqueous extraction of Guduchi at the dose $80 \mu \mathrm{g} / \mathrm{ml}$ did not show any inhibition in the macrophage cell viability. But when the drug 
administered after $24 \mathrm{~h}$ and $48 \mathrm{~h}$ of treatment in 5-fold concentration, the observations showed $10 \%$ inhibition and $90 \%$ viability of macrophages (J774A). Various studies believed that increased in antimicrobial, antitumorous capability of stimulated macrophages is associated to the remarkable positive response in the production of oxygen metabolites. The production of $\mathrm{H}_{2} \mathrm{O}_{2}$ and the oxidation of NAD (P)H are directly dependent upon NAD (P)H-oxidase which localised in plasmalemma. It is believed that Myeloperoxidase involved in augmenting the cytotoxic response of $\mathrm{H}_{2} \mathrm{O}_{2}$. In this study, the macrophage cell line $\mathrm{J} 774 \mathrm{~A}$ treated with aqueous extraction of Tinospora cordifolia (guduchi) showed enhancement in NADHoxidase and the activation of J774A cells activation assessed by biochemical assays. These results suggested that high NADHoxidase, activities may be the reason for antitumorous and antimicrobial properties via macrophage activation. (22)

A study reported the immunostimulator effect when mice treated with aqueous extract of Tinospora cordifolia. All mice were treated with intraperitoneal dose of aqueous extract of Tinospora cordifolia $12.5 \mathrm{mg} / \mathrm{kg}$ (G1-4A) and peritoneal exudate cells (PEC) were procured from peritoneal flush by using $5 \mathrm{ml}$ ice-cold RPMI medium for the duration of 24,48 and $72 \mathrm{~h}$ after administration. The control group was treated with saline and isolated peritoneal exudate cells. The peritoneal exudate cells were mixed with FITC-labelled bio particles and kept for centrifuge process for $15 \mathrm{sec}$ for their interaction and they are incubated at $37{ }^{\circ} \mathrm{C}$ for half hour. After that, the phagocytosis was stopped by using Ice-cold PBS (Phosphate buffered saline). These cells were distributed in a flow cytometer immediately with or without crystal violet to differentiate the presence of surface bound bacteria from phagocytosed bacteria. (29) The phagocytic activity of PEC isolated from mice 24, 48 and $72 \mathrm{~h}$ after intraperitoneal administration of aqueous extract of Tinospora cordifolia 12.5 $\mathrm{mg} / \mathrm{kg}$ as compared to control mice group, the percentage of phagocytosis is significantly high after $24 \mathrm{~h}$ in treated mice. The phagocytic index of PEC, after $48 \mathrm{~h}, 72 \mathrm{~h}$ after the administration of $G 1-4 A$, there was no such significant difference. The study on Tinospora cordifolia extracts, have been shown the wound healing and phagocytic properties of macrophages in a clinical trial. $(30,31)$ Pretreatment of mice with $G 1-4 A$ for $24 \mathrm{~h}$ significantly improved the phagocytic index of the PEC. The increase in phagocytic efficacy of peritoneal exudate cells treated with aqueous extract of Tinospora cordifolia, it was also accompanied by enhancement in the expression of CD11b, which is component of complement receptor-3. (23)

The immunomodulatory activity of different fractions and extracts of stem of Tinospora cordifolia were studied and evaluated using the polymorphonuclear neutrophil (PMN) phagocytic function studies. The extractions of Tinospora cordifolia were subjected to chromatographic purification, which was help to isolate the seven compounds. The study on immunomodulatory potential of these isolated compounds was also observed by using the PMN phagocytic function test. Activation of the reactive oxygen species (ROS) in vitro by the isolated compounds was estimated by using three different assays viz. the nitroblue tetrazolium (NBT), nitrous oxide (NO) and chemiluminescence assays. The viability of all the samples was examined by using the Trypan blue dye exclusion between the concentration ranges of $5-100 \mu \mathrm{g} / \mathrm{ml}$, but for compound 1, it was $0.5-5 \mu \mathrm{g} / \mathrm{ml}$. Those concentrations having atleast $90 \%$ viability were selected for actual study. The different viability results showed that viability affected at higher concentrations at the range of $75 \mu \mathrm{g} / \mathrm{ml}$ onwards in case of the four fractions i.e. methanol extract, ethyl acetate, n-hexane and water fractions. In case of n-butanol and chloroform fractions, viability was affected at $50 \mu \mathrm{g} / \mathrm{ml}$. Hence, a concentration range of $1-$ $50 \mu \mathrm{g} / \mathrm{ml}$ was selected for all these test samples. Further on study it was observed that viability was marginally affected at concentration $5 \mu \mathrm{g} / \mathrm{ml}$ for compound 1 . So all studied concentration were selected for 
further studies. For hot water extract, compounds (2-6) it was observed that viability was affected at all the tested concentrations. For testing the viability activity, concentration range lower than selected was used i.e. $0.01-2.5 \mu \mathrm{g} / \mathrm{ml}$. The Methanol extract compounds have dosed dependent decreased the percent phagocytosis with maximum effect, non-significant as compare to vehicle control. The value of dose dependent increased with maximum response at $0.5 \mu \mathrm{g} / \mathrm{ml}$. For n-Hexane fraction, an increase in the percent phagocytosis with maximam effect was seen at $0.1 \mu \mathrm{g} / \mathrm{ml}$. On examine the phagocytic index, the maximum response was observed at $10 \mu \mathrm{g} / \mathrm{ml}$. For Chloroform fraction, dose dependent increased at $1 \mu \mathrm{g} / \mathrm{ml}$, which was significantly higher than vehicle control. For Ethyl acetate fraction dose dependent increase was assessed with maximum effect at $5 \mu \mathrm{g} / \mathrm{ml}$ and was significantly higher effect than vehicle control. On study different dose concentration, the phagocytic index with maximum response was at $10 \mu \mathrm{g} / \mathrm{ml}$ and significantly higher than vehicle control. In nButanol fraction, study on phagocytic index, a dose dependent increase was observed with maximum effect at $0.5 \mu \mathrm{g} / \mathrm{ml}$ which was significantly high as compare to vehicle control, whereas dose dependent decrease in percentage of phagocytosis observed at $0.1 \mu \mathrm{g} / \mathrm{ml}$. on observing Water fraction, the response was opposite that of other fractions at higher dose concentrations it was not significant. The percentage of phagocytosis with maximum effect at dose $0.5 \mu \mathrm{g} / \mathrm{ml}$ was significantly higher than vehicle control. Hot water extract, $0.25 \mu \mathrm{g} / \mathrm{ml}$ dose dependent showed the maximum response in percentage of phagocytosis and was significant high. From study it is observed that, two compounds were isolated for the first time from natural sources were formed in a mixture and were found active at concentration $1 \mu \mathrm{g} / \mathrm{ml}$ in the PMN phagocytic function tests. It was also observed that the mixture also enhanced rective oxygen species generation at concentration $0.5-1 \mu \mathrm{g} / \mathrm{ml}$ when test by using the NBT, NO, chemilunescence assays and was equivalent to standard immunomodulator PMA. Further, explanation the other three compounds were also found active in PMN function study and increase the reactive oxygen species at concentration $0.1-0.5 \mu \mathrm{g} / \mathrm{ml}$. The overall study on various compounds, it is indicated that the immunemodulatory activity of Tinospora cordifolia may be credited to the synergistic effect of groups of compounds. (24) In Ayurvedic texts too, same indications also have been described on the basis of their, chemical constituents for polar, hydroalcohol and lipid dosage formulations. (32) Since Tinospora cordifolia is already well explored and studied for immunomodulatory effect involving stimulation of phagocytosis in vivo models, $(33,34)$ the active compounds of the present study may show the same immunemodulatory potential in vivo models. (24)

Phagocytosis is cell defence mechanism which is fight against foreign, non-selfmaterials and used as nonspecific immunological parameter to assess the process of immune function. (35) The dysfunction of immune system is responsible for various diseases like viral, bacterial, arthritis, ulcerative colitis, asthma, allergy, parasitic diseases, cancer and infectious diseases. (36) The different extracts of Tinospora cordifolia possessed many beneficial and medicinal properties including antiinflammatory, antiarthritic, antimalarial, aphrodisiac, (37) antiallergic, (38) antidiabetic, (39) antihepatotoxic, (40, 41) andanti-pyretic. (42) The immune cells and their mediators are generally involved in the removal of pathogens, microorganisms by phagocytosis, lysis of bacteria, viruses or tumour cells. The number of malignant diseases like cancers of different origins is caused by alteration in the process or function of immune cells. (43) The synergistic effect of Tinospora cordifolia attributed by various compounds helps its immunomodulatory activity. (24) In reference by various Ayurvedacharya, Tinospora cordifolia has several therapeutic properties as discussed. (44) The pharmacological activities of the Tinospora cordifolia is due to its various 
chemical constituents like diterpenoid lactones, glycosides, steroids, sesquiterpenoid, phenolics, aliphatic compounds, essential oils, a mixture of fatty acids, and polysaccharides which is present in a different parts of the plant leaves, root, stem, and whole part. (45) Singh et al., has reported silver nanoparticles from the stem of Tinospora cordifolia, possessed the antibacterial activity against the different strains of bacteria's. (46) It is reported that Tinospora cordifolia extract is highly recommended against the Parkinosonism. The study done animals, observed the antiinflammatory activity of aqueous extract in 1methyl-4-phenyl-,2,3,6-tetra hydropyridine (MPTP)-intoxicated Parkinsonian mouse model. (47) It was assessed that extract of Tinospora cordifolia reversed the behaviour of the target MPTP-intoxicated mice, which significantly protected the dopaminergic neurons by suppressing neuroinflammation in MPTP-induced Parkinsonian mouse model. (48) Since Tinospora cordifolia is already well explored and explained for immunomodulatory effect by involving stimulation of phagocytosis in vivo models. (32-34) Ethanolic extract of T. cordifolia at the dose of $100 \mathrm{mg} / \mathrm{kg}$ gives significant antistress activity in all parameters compared with standard drug diazepam (dose of 2.5 $\mathrm{mg} / \mathrm{kg}$ ). (48) The plant extract gives a moderate degree of behaviour disorders and mental deficit response. The clinical research showed the improved I. Q level of patients. In Ayurveda, it acts as Medhya Rasayana or brain tonic by increasing mind power like memory and recollection. (49) A study was also conducted to evaluate the role of Tinospora cordifolia on vyadhikshtama in children have shown that rate of infection was less in the test group which were administered orally at a dose of $100 \mathrm{mg} / \mathrm{kg}$ body weight twice daily with honey for 2 months. (50) Another study carried out in Human Immuno-deficiency Virus (HIV) positive patients showed this plant to reduce total leucocyte count (TLC), neutrophil and eosinophil counts. (51) Available evidences support and validates ancient Ayurveda claims such as Rasayana role and disease preventive and health promotive properties of Tinospora cordifolia. (52)

\section{Conclusion}

A number of studies substantiate immunomodulatory claims of Tinospora cordifolia. The botanical is reported to possess multi-targeted role with wide range of therapeutic activities. Above discussed reports show that the Tinospora extracts in aqueous or alcoholic preparation have many active compounds in the form of alkaloids, glycosides, lactones and steroids and all these chemical constituents exhibit their immunomodulatory effect through its macrophage activity. The future scope for the review on various properties of Tinospora Cordifolia remains for developing the biochemical and signalling pathways of its active components, to enable its effectiveness in diseases targeting.

\section{Acknowledgements}

I would like to express my gratitude to Himalayan Journal of Health Sciences who gave me the opportunity to publish the article.

Financial Disclosure statement: The author received no specific funding for this work.

\section{Conflict of Interest}

The author declares that there is no conflict of interest regarding the publication of this article.

\section{References}

1. Singh Bhanu Pratap, Concept of Immunomodulation In Ayurveda and Some Immunomodulatory Herbs. Volume 3.

2. Sharma R, Prajapati PK. Diet and lifestyle guidelines for diabetes: Evidence based ayurvedic perspective. Romanian Journal of Diabetes Nutrition and Metabolic Diseases. 2014; 1;21(4):335-46.

3. Sharma R, Kumar V, Ashok BK, Galib R, Prajapati PK, Ravishankar B. Evaluation of hypoglycaemic and anti-hyperglycaemic activities of Guduchi Ghana in Swiss albino mice. Int J Green Pharm. 2013;7:145-8.

4. Sharma R, Kumar V, Ashok BK, Galib R, Prajapati PK, Ravishankar B. Hypoglycemic and 
anti-hyperglycemic activity of Guduchi Satva in experimental animals. AYU. 2014. 4; 217-20.

5. Sharma R, Shukla VJ, Ravishankar B, Prajapati PK. The effect of two different dosage forms of Guduchi i.e. Satva and Ghana WSR antihyperglycemic effect on madhumeha (NIDDM) [dissertation], Gujarat Ayurved University, IPGT and RA, Jamnagar. 2012;132133.

6. Gupta R, et al. Global Research on Tinospora cordifolia (Medicinal Plant) with Special Reference to India: A Scientometric Assessment Publications Output during 2001-2016. Int J Pharmacogn Chinese Med. 2018; 2(4): 000141.

7. Dhama K, Sachan S, Khandia R, Munjal A, Iqbal HMN, Latheef SK, Karthik K, Samad HA, Tiwari R, Dadar M. Medicinal and Beneficial Health Applications of Tinospora cordifolia (Guduchi): A Miraculous Herb Countering Various Diseases/Disorders and its Immunomodulatory Effects. Recent Pat Endocr Metab Immune Drug Discov. 2017; 10(2):96-111. doi: 10.2174/18722148116661703011051 01.

8. Aher VD, Wahi AK. Pharmacological Study of Tinospora Cordifolia as an Immunomodulator. Int J Curr Pharm Res 2010; 2(4):52-4.

9. Sharma R, Amin H. Rasayana Therapy: Ayurvedic contribution to improve quality of life. World J. Pharmacol. Res. Tech. 2015;4:23-33.

10. Sharma R, Hazra J, Prajapati PK. Nanophytomedicines: A Novel Approach to Improve Drug Delivery and Pharmacokinetics of Herbal Medicine. Bio Bull. 2017;3(1):132-5.

11. Prajapati R, Sharma R, Prajapati PK. Physicochemical evaluation of guduchyadi kwatha for instant use: An ayurvedic herbal formulation. Journal of Pharmaceutical Research International. 2014: 2599-613.

12. Sharma R, Galib R, Prajapati PK. Antimicrobial evaluation of Svarasa Bhavita Guduchi Churna (levigated powder of Tinospora cordifolia (Willd.) Miers with its juice). Ayurscientifica 2017;1(1):25-30.

13. Sharma R, Amin H, Galib, Prajapati PK. Validation of standard manufacturing procedure of Guduci sattva (aqueous extract of Tinospora Cordifolia (Willd.) Miers) and its tablets. Anc Sci Life 2013;33:27-34.

14. Sharma R, Kabra A, Rao MM, Prajapati PK. Herbal and Holistic solutions for Neurodegenerative and Depressive disorders: Leads from Ayurveda. Curr. Pharm. Des. 2018; 27(3): 2597-2608.

15. Sharma R, Kuca K, Nepovimova E, Kabra A, Rao MM, Prajapati PK. Traditional Ayurvedic and herbal remedies for Alzheimer's disease from bench to bedside. Expert Rev. Neurother. 2019; 19: 359-374.

16. Sharma R, Martins N. Telomeres, DNA damage and ageing: potential leads from Ayurvedic
Rasayana (anti-ageing) drugs. J Clin Med. 2020;9(8):2544.

17. Sharma R, Galib R, Prajapati PK. Validation of standard manufacturing procedure of Guduchi Ghana [dried aqueous extract of Tinospora Cordifolia (Willd.) Miers] and its tablets. Ayurpharm Int J Ayurveda Allied Sci. 2013;2:224-32.

18. Kapil A., Sharma S. Journal of Ethnopharmacology. 1997; 58:89-95.

19. Gupta MS, Sharma GD, Chakraborty B. Effect of aqueous extract of Tinospora cordifolia on functions of peritoneal macrophages isolated from $\mathrm{CCl} 4$ intoxicated male albino mice. BMC Complementary \& Alternate Medicine. 2011; 119102.

20. Upadhyaya R, PR, Sharma V, Anita KV. Assessment of the multifaceted immunemodulatory potential of the aqueous extract of Tinospora cordifolia. Res J Chem Sci.2011;1:719.

21. Sudhakaran DS, Srirekha P, Devasree LD, Premsingh S, Michael RD. Immunostimulatory effect of Tinospora cordifolia Miers leaf extract in Oreochromis mossambicus. Indian J Exp Biol. 2006; 44:726-32.

22. More P, Pai K. In vitro NADH-oxidase, NADPHoxidase and myeloperoxidase activity of macrophages after Tinospora cordifolia (guduchi) treatment. Immunopharmacol Immunotoxicol. 2012; 34:368-72.

23. Raghu R, Sharma D, Ramakrishnan R, Khanam S, Chintalwar GJ, Sainis KB. Molecular events in the activation of $\mathrm{B}$ cells and macrophages by a nonmicrobial TLR4 agonist, G1-4A from Tinospora cordifolia. Immunol Lett.2009;123:60-71.

24. Sharma U, Bala M, Kumar N, Singh B, Munshi RK, Bhalerao S. Immunomodulatory active compounds from Tinospora cordifolia. J Ethnopharmacol. 2012; 141:918-26.

25. Wazir V, Maurya R, Kapil R S. Cordioside, a clerodane furano diterpene glucoside from Tinospora cordifolia. Phytochemistry.1995; 38(2):447-449.doi.org/10.1016/00319422(94)00601-O.

26. Ram J., Kapil, A., Guru, P.Y., 1990. Antileishmanial and immunoadjuvant activities of rationally designed thiopyrim-idines. Indian $\mathrm{J}$. Chem. 29: 1129-1133.

27. Beatty J.D, Beatty, B.G, Vlahos, W.G. Measurement of monoclonal antibody affinity by non-competitive enzyme immunoassay. J. Immunol. Methods 100. 1987: 173-179.

28. Czuprynski CJ, Henson PM, Campbell PA: Killing of Listeria monocytogenes by inflammatory neutrophils and mononuclear phagocytes from immune and non immune mice. J Leuk Biol. 1984; 35:193-208. 
29. Lehmann AK, Sornes S, Halstensen A. Phagocytosis: measurement by flow cytometry. J Immunol Methods 2000; 243:229-42.

30. Lehmann AK, Sornes S, Halstensen A. Phagocytosis: measurement by flow cytometry. J Immunol Methods 2000; 243:229-42.

31. Rege N, Bapat RD, Koti R, Desai NK, Dahanukar S.Immunotherapy with Tinospora cordifolia: a new lead in the management of obstructive jaundice. Indian J Gastroenterol.1993;12:5-8.

32. Panchabhai T.S, Kulkarni U.P, Rege N.N. Validation of therapeutic claims of Tinospora cordifolia: a review. Phytotherapy Research. 2008; 22:425-441.

33. Dahanukar S.A., Thatte, U.M., Rege, N.N. Immunostimulants in Ayurveda medicine. In: Wagner, H. (Ed.), Immunomodulatory Agents from Plants. Switzerland: Berkhauser Verlag, Basel. 1999.p. 289-323.

34. Rege N.N., Thatte, U.M., Dahanukar, S.A. Adaptogenic properties of six Rasayana herbs used in Ayurvedic medicine. Phytotherapy Research. 1999; 13:275-291.

35. Galloway T S, Depledge M H, Immunotoxicity in invertebrates: measurement and ecotoxicological relevance National Library of Medicine. 2001 Feb; 10(1):5-23.

36. Patwardhan B., Kalbag, D., Patki, P.S., Nagsampagi, B.A. Search of immunomodulatory agents. Indian Drugs. 1990; 28:56-63.

37. Rao S.K., Rao, S.P., Rao, N.B. Preliminary investigation of the radio sensitizing activity of Guduchi (Tinospora cordifolia) in tumor bearing mice. Phototherapy Research.1990; 22:1482-1489.

38. Nayampalli S.S, Desai, N.K, Ainapure, S.S. Antiallergic properties of Tinospora cardifolia in animal models. Indian Journal of Pharmacy. 1986; $18: 250$.

39. Wadood N, Wadood, A, Shah, S.A. Effect of Tinospora cordifolia on blood glucose and total lipid levels of normal and alloxan-diabetic rabbits. Planta Medica. 1992; 58:31-136.

40. Bhupindu S., Sharma, M.L., Gupta, O.P., Atal, C.K. Antihepatotoxic activity of Tinospora cordifolia Miers. Indian Journal of Pharmacology. 1981;1:96.

41. Rege N.N, Dahanukar, S.A. Karandikar, S.M. Hepatoprotective effects of Tinospora cordifolia against carbon tetrachloride induced liver damage. Indian Drugs. 1984; 21:544-555.

42. Kumar A., Shrivastav, S. A study of antipyretic effect of Guduchi. Sachitra Ayurved. 1995; 48:289-291.

43. Wagner $\mathrm{H}$, Jurcic K. Assays for immunomodulation and effects on mediators of inflammation. In: Dey, P.M., Harborne, J.B. (Eds.), Methods in Plant Biochemistry. London: Academic Press. 1991.p. 195-217.

44. Meena A.K, Singh A, Panda P, Mishra S, Rao M.M. Tinospora cordifolia: Its bioactivities \& evaluation of physicochemical properties, IJPPR. 2010; 2:50-55.

45. Khan M.M, dul Haque M.S, Chowdhury M.S. Medicinal use of the unique plant Tinospora cordifolia: evidence from the traditional medicine and recent research. Asian J. Med. Biol. Res. 2016;2: 508-512.

46. Singh K, Panghal M, Kadyan S, Chaudhary U, Yadav J.P. Antibacterial activity of synthesized silver nanoparticles from Tinospora cordifolia against multi-drug resistant strains of pseudomonas aeruginosa isolated from burn patients. J. Nanomed. Nanotechnol. 2014;5:1-6.

47. Birla H., S.N. Rai, S.S. Singh, W. Zahra, A. Rawat, N. Tiwari, R.K. Singh, A. Pathak, Singh S.P. Tinospora cordifolia suppresses neuroinflammation in Parkinsonian mouse model. NeuroMolecular Med. 2019; 21:42-53.

48. Sarma D.N.K, Khosa R.L, Chaurasia J.P.N., Sahai M. Antistress activity of Tinospora cordifolia and Centella asiatica extracts. Phytother Res. 1996; 10:181-184.

49. Baghel P. Plant of versatile properties of Tinospora cordifolia (Guduchi). IJAIR. 2017; 5:751-753.

50. Sharma N.D, Sharma A. Tinospora cordifolia Enhances Vyadhikshamatwa (immunity) in Children. The Journal of Phytopharmacology. 2015; 4(4):227-230.

51. Kalikar M.V., Thawani VR, Varadpande UK, Sontakke SD, Singh RP, Khiyani RK. Immunomodulatory effect of Tinospora cordifolia extract in human immuno-deficiency virus positive patients. Indian J Pharmacol 2008; 40(3):107-10.

52. Sharma R, Amin H, Prajapati P, Ruknuddin G. Therapeutic Vistas of Guduchi (Tinospora cordifolia): A medico-historical memoir. J. Res. Educ. Ind. Med. 2014;XX, 113-128. 